\title{
Feeding Calcium Salts of Linseed Oil on Productive Performance and Milk Fatty Acid Profile in Grazing Dairy Cows
}

\author{
Yaliska Moreno González ${ }^{1}$, Jesica Iorio¹, María Florencia Olmeda², Dino Curletto3 \\ Daniel Scandolo3, Martín Guillermo Maciel $^{3}$, Alejandra Cuatrin ${ }^{3}$, Rafael Alejandro Palladino ${ }^{2,4}$, \\ Carolina Pérez ${ }^{5}$, Eloy Eduardo Salado ${ }^{3 *}$
}

\author{
${ }^{1}$ Faculty of Agriculture, University of Buenos Aires, Buenos Aires, Argentina \\ ${ }^{2}$ Faculty of Agricultural Science, National University of Lomas de Zamora, Buenos Aires, Argentina \\ ${ }^{3}$ INTA (National Institute of Experimental Agriculture), Research Station Rafaela, Rafaela, Santa Fe, Argentina \\ ${ }^{4}$ CONICET (National Research Council of Argentina), Buenos Aires, Argentina \\ ${ }^{5}$ INTA (National Institute of Experimental Agriculture), Food Technology Institute, Castelar, Buenos Aires, Argentina \\ Email: *salado.eloy@inta.gob.ar
}

How to cite this paper: González, Y.M., Iorio, J., Olmeda, M.F., Curletto, D., Scandolo, D., Maciel, M.G., Cuatrin, A., Palladino, R.A., Pérez, C. and Salado, E.E. (2020) Feeding Calcium Salts of Linseed Oil on Productive Performance and Milk Fatty Acid Profile in Grazing Dairy Cows. Open Journal of Animal Sciences, 10, 761-781.

https://doi.org/10.4236/ojas.2020.104050

Received: September 22, 2020

Accepted: October 27, 2020

Published: October 30, 2020

Copyright $\odot 2020$ by author(s) and Scientific Research Publishing Inc. This work is licensed under the Creative Commons Attribution International License (CC BY 4.0).

http://creativecommons.org/licenses/by/4.0/

\begin{abstract}
The objective of this study was to determine the effect of supplying calcium salts of linseed oil (Ca-FA) rich in omega-3 ( $\alpha$-linolenic acid) on the production and chemical composition of milk and its nutraceutical value in dairy cows in early lactation. The trial lasted 12 weeks ( 2 weeks for adaptation to lipids and 10 weeks of data collection). A total of 36 Holstein dairy cows with $58.0 \pm 17.0$ days in milk (DIM), $594.1 \pm 92.4 \mathrm{~kg} \mathrm{BW}, 2.6 \pm 1.5$ parity and 38.9 $\pm 9.3 \mathrm{~kg}$ milk day $^{-1}$ were used in a randomized complete block design. The treatments were: 1) Omega-3 (O3): $5.2 \mathrm{~kg} \mathrm{DM} \mathrm{day}^{-1}$ of concentrate including $0.7 \mathrm{~kg} \mathrm{DM}$ of Ca-FA + $13.5 \mathrm{~kg} \mathrm{DM}^{-1 a y^{-1}}$ of partial mixed ration (PMR) + 12 $\mathrm{kg} \mathrm{DM} \mathrm{day}{ }^{-1}$ of alfalfa pasture (Medicago sativa) and 2) Control (C): diet similar to $\mathrm{O} 3$ but lipid supplementation was replaced by cracked corn grain so that the diets were isoenergetic. No treatment effect was detected $(P>$ $0.05)$ for any milk production and composition variables, except for urea in milk that was slightly higher in $\mathrm{O} 3(P=0.02)$. The treatment $\times$ week interaction was significant $(P<0.05)$ for fat yield and content, with differences $(P<$ $0.01)$ only in the 3 rd week of the data collection period in favor of group $C$ $\left(1.39\right.$ vs. $1.13 \mathrm{~kg} \cdot \mathrm{day}^{-1}$ and $3.86 \%$ vs. $3.23 \%$ for fat yield and content, respectively). Total DMI and PMR were similar $(P>0.05)$ between treatments. Concentrate intake was higher $(P<0.01)$ in $\mathrm{C}$ compared with $\mathrm{O} 3$. Pasture DMI tended $(P=0.06)$ to be greater for cows that received the $\mathrm{O} 3$ treatment compared with $\mathrm{C}$. Total metabolizable energy (ME) intake was similar $(P=$ $0.44)$ between treatments. No treatment effect was detected $(P>0.05)$ in ru-
\end{abstract}


men environment parameters. Supplementation with $\mathrm{Ca}-\mathrm{FA}$ reduced $(P<$ 0.05) the hypercholesterolemic fraction of milk (C12:0, C14:0 and C16:0, $-13.6 \%,-7.4 \%$ and $-9.0 \%$, respectively). The concentration of $\alpha$-linolenic acid $\left(\mathrm{C}_{18: 3 \mathrm{n}-3}\right)$ increased $(108 \%, P<0.01)$ in $\mathrm{O} 3$ group compared with group $\mathrm{C}$. The absence of negative effects of lipids on the fat content of milk and ruminal fermentation suggests that protection by saponification was effective. The supplementation with Ca-FA $\left(0.85 \mathrm{~kg} \cdot \mathrm{day}^{-1}\right)$ improved the healthy value of the milk.

\section{Keywords}

Dairy Cow, Calcium Salts of Linseed Oil, $\alpha$-Linolenic Acid, Nutraceutical Value

\section{Introduction}

The genetic progress achieved by dairy herds implies working with rations that are increasingly concentrated in energy, exceeding what is offered by pasture and classic supplements. Energy is the main nutritional limitation for milk production [1] and any strategy aimed to increase its consumption would result in a greater quantity of milk produced. Cereal grain-based concentrates increase energy consumption and the fermentable energy/protein ratio in the ration improving the synthesis of microbial protein in the rumen [2]. However, at high doses, ruminal $\mathrm{pH}$ decreases and fiber digestibility is reduced in the rumen, increasing the risk of ruminal acidosis [2]. The negative effects associated with a high starch intake could be mitigated by using lipid energy that is a non-fermentable source in the rumen [3].

The inclusion of lipids in dairy cow diets to increase energy intake is a valid strategy in pasture-fed high genetic merit animals, since fats contain three times more lactation net energy than carbohydrate-rich foods and proteins [4]. An improvement in the efficiency of energy utilization is also expected due to a decrease in heat, methane and urine losses and because the absorbed fatty acids (FA) can be directly incorporated into the fat of the milk, which is a highly efficient process [4]. Furthermore, supplementation with unsaturated FA would provide unsaturated FA precursors and other milk isomers of great importance for human health [5]. However, supplementation with unprotected lipids can cause negative effects on ruminal fermentation and reduce the digestion of cell wall constituents [6]. The magnitude of these effects depends on the degree of saturation of the FA; being the unsaturated FA more detrimental. To avoid the potential negative effects of polyunsaturated FA (PUFA) at rumen level, calcium or magnesium salts of FA are synthesized which are not available for rumen microorganisms when $\mathrm{pH}$ is approximately 6.0 - 6.5. In conditions of higher acidity (post-ruminal tract), the FA release the calcium and are available for intestinal absorption [7]. 
The calcium salts of FA based on palm oil (44\% of C16:0) and oleic acid ( $40 \%$ of $\mathrm{C} 18: 1$ ) evaluated in grazing experiments showed positive effects ( $9 \%$ to $11 \%$ increase) on milk production [8] [9]. Supplementation with high-melting point hydrogenated vegetable oil also increased (9\% to $12 \%$ ) milk production [3] [10]. Nevertheless, the results obtained using PUFA calcium salts are more limited. These products may be less stable and present a certain degree of dissociation at the ruminal level due to the low $\mathrm{pH}$ that is usually observed in dairy cows grazing high quality pastures. This could alter the ruminal function and the productive response.

On the other hand, the milk FA composition is a determining factor in its nutritional quality since it has been shown that some FA exert a positive impact on human health. Consequently, interest has increased in adding value to milk and dairy products by increasing the levels of specific PUFA, such as linoleic acids (C18:2n-6) and $\alpha$-linolenic (C18:3n-3), due to their beneficial properties [11]. Linseed oil is rich in C18:3n-3, which has been shown to have potentially cardio protective effects [12], associated with a lower incidence of hypertension, inflammation and atherosclerosis [11]. Supplementation with linseed oil calcium salts seems to be a valid option to increase the content of C18:3n-3 in milk fat, increasing the nutraceutical value of milk [13].

Previous research evaluating PUFA calcium salts supplements were conducted under confinement conditions where ruminal $\mathrm{pH}$ values ranged between 6.1 and 6.4 [6]. To the author's knowledge, there are no previous reports investigating the effect of calcium salts of linseed oil under grazing conditions. The objective of this study was to determine the effects of supplementation with linseed oil calcium salts to grazing dairy cows in the first third of lactation on the production and composition of milk, the ruminal environment and the FA profile of the milk.

\section{Materials and Methods}

\subsection{Experimental Site, Animals and Treatments}

Thirty six Holstein dairy cows were used (with $58.0 \pm 17.0$ DIM, $594.1 \pm 92.4 \mathrm{~kg}$ BW, $2.6 \pm 1.5$ parity and milk production of $38.9 \pm 9.3 \mathrm{~kg} \cdot \mathrm{day}^{-1}$ ) selected from the research dairy herd of the National Institute of Agricultural Technology (INTA), located in Rafaela, province of Santa Fe, Argentina ( $\left.31^{\circ} 12^{\prime} \mathrm{S}, 61^{\circ} 30^{\prime} \mathrm{W}\right)$, in a 12-week trial ( 2 weeks for adaptation to lipids and 10 weeks of data collection) from August to December 2015. Cows were blocked (18 blocks) by DIM, parity, BW and milk production and randomly assigned to one of two treatments within each block: Omega-3 (O3) or Control (C).

During the 3 weeks prior to the start of the trial (covariate), the cows received the $\mathrm{C}$ diet. All cows were equipped with neck transponders that served to record daily milk production on an individual basis (ALPRO version 6.60/DeLaval, Tumba, Sweden). Diets were formulated to meet the requirements of a Holstein dairy cow of $600 \mathrm{~kg}$ BW, with $60 \mathrm{DIM}$, producing $42.0 \mathrm{~kg} \cdot \mathrm{day}^{-1}$ of milk with 
$3.7 \%$ fat [14]. Two isoenergetic diets were formulated for the study. O3 diet contained $0.85 \mathrm{~kg} \cdot \mathrm{day}^{-1}$ of a calcium salt of linseed oil $(82.3 \% \mathrm{DM}, 13.2 \%$ ash, 86.8\% ether extract and $36.0 \%$ of C18:3 n-3) per cow whereas C diet compensated the energy with cracked corn grain ( $1 \mathrm{~kg}$ DM lipids $=2 \mathrm{~kg}$ DM corn grain). All cows received the same management and were fed together but differentially supplemented at milking time except for the times when PMR dry matter intake (DMI) were measured. After the a.m. $(02.30 \mathrm{~h})$ and p.m. $(01.30 \mathrm{~h})$ milkings, the cows were located in a dry-lot for the supply of the PMR. Once the target PMR intake was finished, they were taken to the grazing plot until the a.m. milking. Alfalfa (Medicago sativa) pasture was offered at a daily rate of $12 \mathrm{~kg}$ DM per cow and PMR at a daily rate of $13.5 \mathrm{~kg}$ DM per cow. The ingredients and nutrients of the experimental diets are presented in Table 1.

For the ruminal environment studies, 12 cows ( 6 per treatment) were selected from the 36 cows used for the trial, considering the previously assigned blocks in order to maintain the initial balance proposed at the time of assigning the treatments. All procedures were approved by the Welfare Committee of the School of Agriculture of Buenos Aires University.

Table 1. Ingredient and nutrient composition of the experimental diets.

\begin{tabular}{|c|c|c|}
\hline \multirow{2}{*}{ Item } & \multicolumn{2}{|c|}{ Dietary treatment } \\
\hline & $\mathrm{O} 3$ & $\mathrm{C}$ \\
\hline \multicolumn{3}{|l|}{ Ingredient, kg DM cow ${ }^{-1}$ day $^{-1}$} \\
\hline Alfalfa & 8.00 & 8.00 \\
\hline Corn silage & 5.88 & 5.88 \\
\hline Soybean meal & 2.71 & 2.71 \\
\hline Ground corn & 2.76 & 2.76 \\
\hline Alfalfa hay & 1.33 & 1.33 \\
\hline Commercial feed & 3.62 & 3.62 \\
\hline Cracked corn & 0.88 & 2.30 \\
\hline Ca-FA & 0.70 & 0.00 \\
\hline \multicolumn{3}{|l|}{ Nutrient } \\
\hline $\mathrm{DM}, \%$ & 40.38 & 41.02 \\
\hline $\mathrm{CP}, \%$ of $\mathrm{DM}$ & 18.31 & 18.26 \\
\hline NDF, $\%$ of DM & 24.35 & 24.22 \\
\hline $\mathrm{ADF}, \%$ of $\mathrm{DM}$ & 13.48 & 13.28 \\
\hline $\mathrm{ADL}, \%$ of $\mathrm{DM}$ & 2.36 & 2.35 \\
\hline $\mathrm{EE}, \%$ of $\mathrm{DM}$ & 6.61 & 4.48 \\
\hline Ash, $\%$ of DM & 7.57 & 7.13 \\
\hline ME, Mcal kg DM"-1 & 2.79 & 2.71 \\
\hline
\end{tabular}

$\mathrm{Ca}-\mathrm{FA}=$ calcium salts of linseed oil; $\mathrm{DM}=$ dry matter; $\mathrm{CP}=$ crude protein; $\mathrm{NDF}=$ neutral detergent fiber; $\mathrm{ADF}=$ acid detergent fiber; $\mathrm{ADL}=$ acid detergent lignin; $\mathrm{EE}=$ ether extract; $\mathrm{ME}=$ metabolizable energy, estimated according to [14]. 


\subsection{Measurements}

\subsubsection{Forage Biomass}

Weekly herbage biomass $\left(\mathrm{kg} \mathrm{DM} \mathrm{ha}^{-1}\right)$ was estimated by means of cuts at $4 \mathrm{~cm}$ height [15] with manual scissors in an area delimited by a metal frame of 0.125 $\mathrm{m}^{2}$, cutting a total area of $1 \mathrm{~m}^{2}$ in each sampling. The total sample, composed of 8 subsamples of $0.125 \mathrm{~m}^{2}$, was dried in an oven at $65^{\circ} \mathrm{C}$ for 48 hours to determine its DM content. Based on this estimate, the area of the daily grazing strips was determined according to the defined herbage allowance.

\subsubsection{Chemical Composition of Feedstuffs}

Representative samples of the concentrate, the PMR, the ingredients that composed it and the pasture were taken every 10 days. The latter were obtained manually in the grazing horizon simulating the selectivity of the cow (hand-plucking) [16]. All samples were dried in an oven with forced air circulation at $65^{\circ} \mathrm{C}$ to constant weight to determine the DM content and grinded in a Wiley mill (1 $\mathrm{mm}$ mesh). The content of ashes ([17], procedure 942.05), total nitrogen (Kjeldhal method; [18], procedure 976.05), crude protein (CP; total nitrogen $\times$ 6.25), neutral detergent fiber (NDF; [19]), acid detergent fiber (ADF; [17], procedure 973.18), acid detergent lignin (ADL; [17], procedure 973.18), ether extract (EE; [18], procedure 920.39) and in vitro DM digestibility (IVDMD; two-stage fermentation technique by [20]) was determined. Lipid metabolizable energy (ME) content $\left(6.50 \mathrm{Mcal} . \mathrm{kg} \mathrm{DM}^{-1}\right)$ was calculated based on the equations from [14].

\subsubsection{Milk Production and Composition}

Milk production was measured individually and daily by the milk measurement system DeLaval ALPRO (DeLaval International AB, Tumba, Sweden), being the weekly averages computed. Average milk production during the pre-experimental period was used as a covariate. Milk composition was evaluated from individual samples collected weekly. Two milk subsamples were taken from each cow in consecutive milkings (morning and afternoon) using milk meters (DeLaval International AB, Tumba, Sweden), then a single individual sample (pool) weighted by the respective production was obtained. In each composite sample the content of fat, total protein, lactose, total solids (TS), non-fat solids (NFS) and urea was determined by infrared spectrophotometry (MilkoScan ${ }^{\mathrm{TM}}$ Minor; FOSS Electric, Hilleroed, Denmark) according to the standard method [21]. Milk casein content was calculated as $6.38 \times($ total $\mathrm{N}-$ non-casein $\mathrm{N})$ after semi Micro-Kjeldahl digestion and colorimetric reading in Technicon continuous flow autoanalyzer according to [22] and that of true protein was estimated according to [14]. Fat-corrected milk (4\% FCM) was calculated according to [23] and energy-corrected milk (ECM) as proposed by [24]. During the last week of the pre-experimental period, an additional milk sample (covariate) was taken.

Individual aliquots of milk $(100 \mathrm{ml})$ were collected in two samplings, during the last week of the pre-experimental period (covariate) and in the sixth week of 
the data collection period and were stored at $-24^{\circ} \mathrm{C}$ for the subsequent determination of the FA profile. A lipid extraction was carried out on each sample according to the protocol of [25]. Alkaline methylation of the FA was carried out with $\mathrm{KOH}$ in methanol according to the [26] procedure and then injected into a Varian gas chromatograph model CP3800, with a PSS (Programmed Temperature Vaporizer) injector, flow divider and flame ionization detector (FID). The FAs' methyl esters were separated using a capillary column CP-Sil $88(100 \mathrm{~m} \times$ $0.25 \mathrm{~mm} \times 0.20 \mu \mathrm{m}$ of Varian CP7489), using helium as carrier. The individual FAs were identified by comparing the relative retention times with individual fatty acid standards (PUFA-2 Animal Source, Grain Fatty Acid Methyl Ester Mix, conjugated Octadecadienoic acid methyl ester, trans-11-Vaccenic Methyl Ester, cis-11-Vaccenic Methyl Ester, trans-9-Elaidic Methyl Ester and 37-Component FAME mix, Sigma-Aldrich, USA). The analytical results were expressed as percentages of the total FA.

\subsubsection{Dry Matter Intake}

Total DM intake was estimated by [14] whilst pasture DM intake was estimated by subtracting PMR and concentrate DM intakes (determined by the difference method) to total DM intake. The estimation of total DM intake was made post hoc based on the level of production and per individual cow in order to generate the necessary variability to later analyze these variables statistically. This methodology for estimating intake was used in previous studies [27] [28].

\subsubsection{Ruminal Environment Parameters}

The characterization of the ruminal environment was carried out by means of $\mathrm{pH}$ measurements, ammonia-nitrogen concentration $\left(\mathrm{NH}_{3}-\mathrm{N}\right)$ and volatile fatty acids (VFA). Briefly, approximately $20 \mathrm{ml}$ of ruminal liquor were extracted from the ventral sac by rumenocentesis [29], carrying out a single sampling. The $\mathrm{pH}$ was measured on these samples with an Altronix portable digital $\mathrm{pH}$ meter, immediately after the ruminal liquor had been extracted and following cheese cloth filtering. Of the $20 \mathrm{ml}$ extracted, $9.9 \mathrm{ml}$ were conserved with $0.1 \mathrm{ml}$ of a $98 \%$ sulfuric acid ( $\mathrm{H} 2 \mathrm{SO} 4)$ solution and frozen at $-20^{\circ} \mathrm{C}$ to later carry out the determination of VFA. Additionally, $4 \mathrm{ml}$ were used to determine $\mathrm{NH}_{3}-\mathrm{N}$, which were conserved with $4 \mathrm{ml}$ of $\mathrm{HCl} 0.2 \mathrm{M}$ and frozen at $-20^{\circ} \mathrm{C}$. After being thawed, the samples were centrifuged at $10,000 \mathrm{~g}$ for $15 \mathrm{~min}$ at $0^{\circ} \mathrm{C}$ (Eppendorf, Centrifuge 5810R model). The determination of the VFA concentration was carried out by gas chromatography with purification with orthophosphoric acid (25\%) in $0.5 \mathrm{M}$ sulfuric acid at a rate of $0.5 \mathrm{ml}$ every $2 \mathrm{ml}$ of sample and centrifuged for $10 \mathrm{mi}-$ nutes at $5000 \mathrm{~g}$ [30]. The ammonia-nitrogen concentration was determined by spectrophotometry (Thermo Fisher Scientific Spectrophotometer, Genesys 10-S model) at the Animal Nutrition Laboratory of the Faculty of Agronomy of the University of Buenos Aires.

\subsection{Statistical Analysis}

The results referring to milk production and composition were analyzed ac- 
cording to a randomized complete block design with repeated observations in time adjusted by covariate $(\alpha=0.05)$. The following model was used:

$$
Y_{i j k l}=\mu+T_{i}+B_{j}+A(B)_{k(j)}+W_{l}+(T \times W)_{i l}+\operatorname{Cov}+E_{i j k l},
$$

where:

$Y_{i j k l}=$ dependent variable, $\mu$ = general mean, $T_{i}=$ treatment effect, $B_{j}=$ block effect, $A(B)_{k(j)}=$ random effect of animal nested to block, $W_{l}=$ sampling week effect, $(T \times W)_{i l}=$ effect of treatment interaction $\times$ sampling week, Cov $=$ covariate and $E_{i j k l}=$ residual error.

The intake data, ruminal environment and milk FA profile were analyzed by means of a model with a classification criterion (treatment):

$$
Y_{i j k}=\mu+T_{i}+B_{j}+A(B)_{k(j)}+E_{i j k},
$$

where:

$Y_{i j k}=$ dependent variable, $\mu=$ general mean, $T_{i}=$ treatment effect, $B_{j}=$ block effect, $A(B)_{k(j)}=$ random effect of animal nested to block and $E_{i j k}=$ residual error.

All statistical analyzes were performed using the MIXED procedure of the SAS statistical package [31].

\section{Results}

\subsection{Chemical Composition of the Pasture}

Taken together, the results of the chemical composition of the pasture used (Table 2) indicated an apparently high quality. The average DM content of the forage (Table 2) was located above the critical range (15\% - 18\%) that would affect voluntary intake [32].

The average $\mathrm{CP}$ content of the pasture (Table 2) was close to the maximum value of the range $(15 \%-25 \%)$ proposed by [33] to obtain a high ruminal degradability of DM. In turn, the average NDF and ADF contents of the pasture (Table 2) were far below the values considered critical (42\% and 30\%, for NDF

Table 2. Chemical composition of pasture ${ }^{1}$.

\begin{tabular}{cc}
\hline Parameter & Values $^{2}$ \\
\hline DM, \% & $20.93 \pm 1.81$ \\
IVDDM, \% & $76.76 \pm 7.74$ \\
CP, \% DM & $25.47 \pm 2.08$ \\
NDF, \% DM & $24.96 \pm 5.31$ \\
ADF, \% DM & $15.71 \pm 3.67$ \\
ADL, \% DM & $3.61 \pm 1.44$ \\
EE, \% DM & $4.98 \pm 2.75$ \\
Ashes, \% DM & $10.97 \pm 0.90$ \\
\hline
\end{tabular}

${ }^{1}$ Perennial alfalfa pasture (Medicago sativa). ${ }^{2}$ Values are expressed as the average \pm the standard deviation. $\mathrm{DM}=$ dry matter; IVDDM = in vitro digestibility of $\mathrm{DM} ; \mathrm{CP}=$ crude protein; $\mathrm{NDF}=$ neutral detergent fiber; $\mathrm{ADF}=$ acid detergent fiber; $\mathrm{ADL}=$ acid detergent lignin; $\mathrm{EE}=$ ether extract. 
and $\mathrm{ADF}$, respectively) in order to achieve maximum DM intake in alfalfa-based pastures [34].

It could then be concluded that the quality parameters of the forage apparently consumed by the cows were adequate to allow high DM intakes.

\subsection{Milk Production and Composition}

Milk, 4\% FCM, ECM and protein yields were similar $(P>0.05)$ between treatments (Table 3$)$. The treatment $\times$ week interaction was significant $(P<0.05)$ for fat yield and content, indicating that the response to lipid supplementation varied depending on the week of lactation, detecting significant differences $(P<$ 0.01 ) between treatments only in the $3^{\text {rd }}$ week of the data collection period in favor of the control group (1.39 vs. $1.13 \mathrm{~kg} \cdot \mathrm{d}^{-1}$ and $3.86 \%$ vs. $3.23 \%$ for fat yield and content, respectively).

The lactose content was not affected $(P=0.17)$ by the supplementation with O3 (Table 3), a result compatible with the similar milk production observed between treatments. The levels of protein, TS, NFS and casein were similar $(P>$ 0.05 ) between treatments (Table 3 ). The urea content in milk was slightly higher ( $+5 \%, P=0.02)$ in the cows supplemented with $\mathrm{O} 3$ compared with the control group (Table 3 ), possibly associated with a lower availability of fermentable energy in the rumen.

Table 3. Milk production and composition in dairy cows supplemented (O3) or not (C) with linseed oil calcium salts $\left(0.85 \mathrm{~kg} \cdot \mathrm{day}^{-1}\right)$.

\begin{tabular}{|c|c|c|c|c|c|c|}
\hline \multirow{2}{*}{ Variable } & \multicolumn{2}{|c|}{ Treatment $^{1}$} & \multirow{2}{*}{ SEM } & \multicolumn{3}{|c|}{$P$-value ${ }^{2}$} \\
\hline & $\mathrm{O} 3$ & $\mathrm{C}$ & & Treat & Week & Treat $\times$ Week \\
\hline Milk, kg. day ${ }^{-1}$ & 33.4 & 33.8 & 0.85 & 0.72 & 0.01 & 0.88 \\
\hline $4 \%$ FCM, kg.day ${ }^{-1}$ & 29.9 & 31.1 & 0.95 & 0.40 & 0.01 & 0.22 \\
\hline $\mathrm{ECM}, \mathrm{kg} \cdot \mathrm{day}^{-1}$ & 29.8 & 30.9 & 0.92 & 0.40 & 0.01 & 0.20 \\
\hline \multicolumn{7}{|l|}{ Fat } \\
\hline$\%$ & 3.31 & 3.47 & 0.08 & 0.21 & 0.01 & 0.02 \\
\hline $\mathrm{kg} \cdot \mathrm{day}^{-1}$ & 1.10 & 1.17 & 0.04 & 0.20 & 0.01 & 0.03 \\
\hline \multicolumn{7}{|l|}{ Total protein } \\
\hline$\%$ & 3.11 & 3.14 & 0.04 & 0.54 & 0.01 & 0.21 \\
\hline $\mathrm{kg} \cdot \mathrm{day}^{-1}$ & 1.03 & 1.06 & 0.03 & 0.41 & 0.01 & 0.52 \\
\hline True protein, $\%$ & 2.89 & 2.92 & 0.04 & 0.54 & 0.01 & 0.21 \\
\hline Lactose, \% & 4.87 & 4.83 & 0.02 & 0.17 & 0.01 & 0.09 \\
\hline TS, \% & 12.14 & 12.27 & 0.12 & 0,50 & 0,01 & 0,16 \\
\hline NFS, \% & 8.75 & 8.72 & 0.04 & 0.53 & 0.01 & 0.78 \\
\hline Casein, \% & 2.49 & 2.48 & 0.02 & 0.60 & 0.01 & 0.45 \\
\hline Urea, \% & 0.039 & 0.037 & 0.001 & 0.02 & 0.01 & 0.20 \\
\hline
\end{tabular}

${ }^{1}$ Values are expressed as the least squares means (LSMeans) and the standard error of the LSMeans (SEM). ${ }^{2}$ Treatment effects (Treat), lactation week (Week) and treatment $\times$ week interaction (Treat $\times$ Week). $4 \%$ FCM = fat-corrected milk; ECM = energy-corrected milk; TS = total solids; NFS = non-fat solids . 


\subsection{Dry Matter and Energy Intake}

PMR and total DM intakes $\left(\mathrm{kg} \cdot \mathrm{day}^{-1}\right)$ were similar $(P>0.05)$ between treatments (Table 4). Concentrate intake was higher $(+33 \%, P<0.01)$ in the control group (Table 4), probably as a consequence of a lower palatability of the concentrate in the $\mathrm{O} 3$ group added to the fact that due to the design of the trial (isoenergetic concentrates) the cows of the control group received $+0.7 \mathrm{~kg} \mathrm{DM} \mathrm{day}^{-1}$ of concentrate.

A trend $(P=0.06)$ to a higher pasture DM intake $(+65 \%)$ was detected in the cows of the $\mathrm{O} 3$ group (Table 4 ), possibly associated with the lower concentrate intake observed in this group. Total ME intake $\left(\mathrm{Mcal}^{\left.-\mathrm{day}^{-1}\right)}\right.$ was $\operatorname{similar}(P=$ 0.44 ) between treatments (Table 4).

\subsection{Ruminal Environment Parameters}

The supplementation with linseed oil calcium salts did not produce significant changes in any of the evaluated ruminal environment parameters (Table 5). Only a trend $(P=0.12)$ to a higher concentration of $\mathrm{NH}_{3}-\mathrm{N}$ in the cows of the O3 group with respect to the control group was observed, which is compatible with the higher levels of urea in milk observed in this group of cows (Table 3 ).

The absence of effect of lipids on the variables associated with the ruminal environment suggests that their protection by saponification was effective.

\subsection{Fatty Acid Profile}

Supplementation with linseed oil calcium salts modified the FA profile of the milk fat (Table 6). The concentration of the FAs C12:0, C14:0 and C16:0

Table 4. Dry matter and metabolizable energy intake in dairy cows supplemented (O3) or not $(\mathrm{C})$ with linseed oil calcium salts $\left(0.85 \mathrm{~kg} \cdot \mathrm{day}^{-1}\right)$.

\begin{tabular}{|c|c|c|c|c|}
\hline \multirow{2}{*}{ Intake } & \multicolumn{2}{|c|}{ Treatment $^{1}$} & \multirow{2}{*}{ SEM } & \multirow{2}{*}{$P$-value } \\
\hline & $\mathrm{O} 3$ & $\mathrm{C}$ & & \\
\hline \multicolumn{5}{|l|}{ DM, kg. day ${ }^{-1}$} \\
\hline Pasture & 5.6 & 3.4 & 0.70 & 0.06 \\
\hline Concentrate & 3.9 & 5.9 & 0.07 & $<0.01$ \\
\hline PMR & 13.1 & 12.8 & 0.11 & 0.08 \\
\hline Total & 22.7 & 22. & 0.80 & 0.61 \\
\hline \multicolumn{5}{|l|}{$\mathrm{ME}^{2},{\text { Mcal } \cdot \text { day }^{-1}}^{-1}$} \\
\hline Pasture & 14.6 & 9.3 & 1.72 & 0.06 \\
\hline Concentrate & 13.7 & 18.0 & 0.23 & $<0.01$ \\
\hline PMR & 34.3 & 33.4 & 0.30 & 0.08 \\
\hline Total & 62.6 & 60.8 & 1.98 & 0.44 \\
\hline
\end{tabular}

${ }^{1}$ Values are expressed as the least squares means (LSMeans) and the standard error of the LSMeans (SEM). ${ }^{2}$ Estimated according to [14]; ME values for pasture, O3 concentrate, C concentrate and PMR: 2.61, 3.50, 3.05 and $2.61 \mathrm{Mcal} \mathrm{kg} \mathrm{DM}^{-1}$, respectively. 
Table 5. Ruminal environment parameters in dairy cows supplemented (O3) or not (C) with linseed oil calcium salts $\left(0.85 \mathrm{~kg} \cdot \mathrm{day}^{-1}\right)$.

\begin{tabular}{|c|c|c|c|c|}
\hline \multirow{2}{*}{ Parameter } & \multicolumn{2}{|c|}{ Treatment $^{1}$} & \multirow{2}{*}{ SEM } & \multirow{2}{*}{$P$-value } \\
\hline & $\mathrm{O} 3$ & $\mathrm{C}$ & & \\
\hline VFA $\left(\mathrm{mmol} \cdot \mathrm{L}^{-1}\right)$ & 94.03 & 94.08 & 6.90 & 0.99 \\
\hline Acetate $\left(\mathrm{mmol} \cdot \mathrm{L}^{-1}\right)$ & 61.07 & 62.40 & 4.84 & 0.85 \\
\hline Acetate $\left(\mathrm{mol} 100 \mathrm{~mol}^{-1}\right)$ & 65.33 & 66.33 & 1.32 & 0.61 \\
\hline Propionate $\left(\mathrm{mmol} \cdot \mathrm{L}^{-1}\right)$ & 24.93 & 22.03 & 2.90 & 0.51 \\
\hline Propionate $\left(\mathrm{mol} 100 \mathrm{~mol}^{-1}\right)$ & 25.80 & 23.33 & 1.62 & 0.33 \\
\hline Butyrate $\left(\mathrm{mmol} \cdot \mathrm{L}^{-1}\right)$ & 8.05 & 9.68 & 1.58 & 0.50 \\
\hline Butyrate $\left(\mathrm{mol} 100 \mathrm{~mol}^{-1}\right)$ & 8.87 & 10.32 & 1.76 & 0.59 \\
\hline Acetate:Propionate ratio & 2.62 & 2.88 & 0.18 & 0.35 \\
\hline $\mathrm{pH}$ & 6.10 & 6.13 & 0.26 & 0.95 \\
\hline $\mathrm{NH}_{3}-\mathrm{N}\left(\mathrm{mg} \cdot \mathrm{dl}^{-1}\right)$ & 19.14 & 16.42 & 1.02 & 0.12 \\
\hline
\end{tabular}

${ }^{1}$ Values are expressed as the least squares means (LSMeans) and the standard error of the LSMeans (SEM). $\mathrm{NH}_{3}-\mathrm{N}=$ ammonia-nitrogen; VFA = total volatile fatty acids.

Table 6. Fatty acid profile of milk fat in dairy cows supplemented (O3) or not (C) with linseed oil calcium salts $\left(0.85 \mathrm{~kg} \cdot \mathrm{day}^{-1}\right)$.

\begin{tabular}{|c|c|c|c|c|}
\hline \multirow{2}{*}{$\begin{array}{l}\text { Fatty Acids, } \\
\text { g. } 100 \text { g FA }^{-1}\end{array}$} & \multicolumn{2}{|c|}{ Treatment $^{1}$} & \multirow{2}{*}{ SEM } & \multirow{2}{*}{$P$-value } \\
\hline & O3 & $\mathrm{C}$ & & \\
\hline C4:0 & 2.08 & 2.09 & 0.092 & 0.95 \\
\hline C5:0 & 0.02 & 0.02 & 0.001 & 0.02 \\
\hline C6:0 & 1.83 & 1.92 & 0.052 & 0.25 \\
\hline $\mathrm{C} 7: 0$ & 0.02 & 0.03 & 0.002 & 0.01 \\
\hline C8:0 & 1.29 & 1.40 & 0.045 & 0.12 \\
\hline C9:0 & 0.03 & 0.04 & 0.004 & 0.02 \\
\hline C10:0 & 3.09 & 3.52 & 0.129 & 0.03 \\
\hline $\mathrm{C} 10: 1+\mathrm{C} 11: 0$ & 0.33 & 0.38 & 0.018 & 0.07 \\
\hline $\mathrm{C} 12: 0$ & 3.50 & 4.05 & 0.153 & 0.02 \\
\hline cis-9 C12:1 & 0.08 & 0.09 & 0.005 & 0.36 \\
\hline $\mathrm{C} 13: 0+$ cis-11 C12:1 & 0.17 & 0.21 & 0.012 & 0.02 \\
\hline i C14:0 & 0.10 & 0.09 & 0.007 & 0.81 \\
\hline C14:0 & 11.08 & 11.96 & 0.235 & 0.02 \\
\hline i C15:0 & 0.25 & 0.24 & 0.009 & 0.45 \\
\hline ai $\mathrm{C} 15: 0$ & 0.46 & 0.45 & 0.012 & 0.38 \\
\hline cis-9 C14:1 & 0.82 & 0.82 & 0.044 & 0.99 \\
\hline $\mathrm{C} 15: 0$ & 0.93 & 1.06 & 0.035 & 0.02 \\
\hline i C16:0 & 0.23 & 0.22 & 0.013 & 0.61 \\
\hline $\mathrm{C} 16: 0$ & 26.54 & 29.40 & 0.597 & $<0.01$ \\
\hline trans-9 16:1 & 0.41 & 0.38 & 0.017 & 0.40 \\
\hline cis-7 16:1 & 0.17 & 0.18 & 0.005 & 0.55 \\
\hline cis-9 16:1 & 1.41 & 1.53 & 0.053 & 0.13 \\
\hline
\end{tabular}




\section{Continued}

\begin{tabular}{|c|c|c|c|c|}
\hline $\mathrm{C} 17: 0$ & 0.56 & 0.58 & 0.015 & 0.37 \\
\hline cis-9 C17:1 & 0.17 & 0.18 & 0.007 & 0.45 \\
\hline C18:0 & 11.52 & 10.75 & 0.450 & 0.25 \\
\hline trans-6/7/8 C18:1 & 0.35 & 0.24 & 0.021 & $<0.01$ \\
\hline trans-9 C18:1 & 0.24 & 0.18 & 0.015 & $<0.01$ \\
\hline trans-10 C18:1 & 0.55 & 0.36 & 0.048 & 0.01 \\
\hline trans-11 C18:1 (VA) & 1.45 & 1.08 & 0.089 & 0.01 \\
\hline trans-12 C18:1 & 0.38 & 0.26 & 0.030 & 0.03 \\
\hline cis-9 C18:1 (oleic) & 20.22 & 18.64 & 0.485 & 0.03 \\
\hline cis-11 C18:1 & 0.67 & 0.69 & 0.029 & 0.69 \\
\hline cis-12 C18:1 & 0.44 & 0.22 & 0.040 & $<0.01$ \\
\hline trans- 16 + cis-14 C18:1 & 0.45 & 0,31 & 0,022 & $<0.01$ \\
\hline trans- 11, trans- $15 \mathrm{C} 18: 2$ & 0.31 & 0.20 & 0.019 & $<0.01$ \\
\hline cis-9, cis-12 C18:2 n-6 & 3.05 & 2.72 & 0.109 & 0.04 \\
\hline Other C18:2 & 0.17 & 0.05 & 0.014 & $<0.01$ \\
\hline$C 18: 3 n-6$ & 0.03 & 0.03 & 0.002 & 0.15 \\
\hline$C 18: 3 n-3$ & 1.00 & 0.48 & 0.069 & $<0.01$ \\
\hline cis-9, trans-11 CLA (RA) & 0.64 & 0.50 & 0.035 & 0.01 \\
\hline Other CLA & 0.02 & 0.02 & 0.001 & 0.52 \\
\hline C20:0 & 0.12 & 0.13 & 0.001 & 0.34 \\
\hline C20:4 n-6 & 0.15 & 0.17 & 0.005 & $<0.01$ \\
\hline C20:5 n-3 (EPA) & 0.05 & 0.03 & 0.003 & $<0.01$ \\
\hline $\mathrm{C} 21: 0$ & 0.04 & 0.02 & 0.003 & $<0.01$ \\
\hline $\mathrm{C} 22: 0$ & 0.38 & 0.46 & 0.080 & 0.50 \\
\hline $\mathrm{C} 22: 4 \mathrm{n}-6$ & 0.03 & 0.03 & 0.004 & 0.18 \\
\hline $\mathrm{C} 22: 5 \mathrm{n}-3$ & 0.07 & 0.05 & 0.002 & $<0.01$ \\
\hline C24:0 & 0.03 & 0.03 & 0.002 & 0.65 \\
\hline Saturated (SFA) & 64.09 & 68.45 & 0.828 & $<0.01$ \\
\hline Monounsaturated (MUFA) & 27.80 & 25.24 & 0.632 & 0.01 \\
\hline Poliunsaturated (PUFA) & 5.50 & 4.28 & 0.209 & $<0.01$ \\
\hline MUFA trans total & 3.29 & 2.51 & 0.185 & 0.01 \\
\hline$n-3$ & 1.12 & 0.56 & 0.071 & $<0.01$ \\
\hline$n-6$ & 3.25 & 2.95 & 0.107 & 0.06 \\
\hline $\mathrm{AI}^{2}$ & 2.36 & 2.90 & 0.114 & $<0.01$ \\
\hline \multicolumn{5}{|l|}{$\mathrm{DI}^{3}$} \\
\hline cis-9 C14:1/14:0 & 0.07 & 0.07 & 0.003 & 0.28 \\
\hline cis-9 C18:1/18:0 & 1.78 & 1.75 & 0.062 & 0.74 \\
\hline RA/VA & 0.45 & 0.58 & 0.033 & 0.02 \\
\hline Ratio n6/n3 & 3.04 & 5.54 & 0.204 & $<0.01$ \\
\hline
\end{tabular}

${ }^{1}$ Values are expressed as the least squares means (LSMeans) and the standard error of the LSMeans (SEM). ${ }^{2} \mathrm{AI}$ : atherogenicity index $(\mathrm{C} 12: 0+4 \times \mathrm{C} 14: 0+\mathrm{C} 16: 0) /\left(\right.$ sum of unsaturated FA). ${ }^{3} \mathrm{DI}: \Delta^{9}$-desaturase index. VA: vaccenic acid; RA: rumenic acid; $n-3$ : omega-3 FA; $n-6$ : omega-6 FA. 
(pro-atherogenic) was lower $(P<0.05)$, while the concentration of oleic acid (cis-9 C18:1) was higher $(+8 \%, P=0.03)$ in the group of cows O3 with respect to group C. In turn, the rumenic acid (RA) (cis-9, trans-11 CLA) increased 28\% ( $P$ $<0.01)$ in group $\mathrm{O} 3$ cows with respect to $\mathrm{C}$, a result compatible with the increase $(P<0.01)$ in the concentration of vaccenic acid (VA) (trans-11 C18:1, precursor in the endogenous synthesis of RA in the mammary gland) in cows supplemented with lipids. Supplementation with $\mathrm{O} 3$ reduced $(P<0.01)$ the concentration of SFA $(-6 \%)$ and increased $(P<0.01)$ the concentrations of MUFA $(+10 \%)$, PUFA (+28\%), acid $\alpha$-linolenic $(\mathrm{C} 18: 3 \mathrm{n}-3)$ and total n-3 FA with respect to the control group.

Finally, linseed oil calcium salts intake significantly reduced $(P<0.01)$ the AI $(-18 \%)$ of milk fat and the $n-6 / n-3$ ratio $(-45 \%)$.

\section{Discussion}

\subsection{Milk Production and Composition}

In this study, after 10 weeks of supplementation, milk production was not significantly modified $(P>0.05)$ by the intake of linseed oil calcium salts (Table 3$)$. The lack of positive effect of unsaturated lipid supplementation on milk production is a frequent result in experiments under grazing conditions [4]. In accord with previous results, the supplementation of grazing primiparous and multiparous cows in the first third of lactation with unsaturated FA calcium salts (0.7 $\mathrm{kg} \cdot \mathrm{day}^{-1}$ ) did not show significant differences in milk production in either of the two categories, averaging $28.3 \mathrm{~kg} \cdot \mathrm{day}^{-1}$ in multiparous cows and $24.6 \mathrm{~kg} \cdot \mathrm{day}^{-1}$ in primiparous cows [35]. Under grazing conditions dry matter and energy intake have been identified as the most limiting components for milk production [1] [2] [36]. In the present trial, the lack of positive effect of supplementation with linseed oil calcium salts on total DM and energy intake (Table 4) could contribute to explain the absence of increases in milk production.

The treatment $\times$ week interaction was significant $(P<0.05)$ for fat yield and content (Table 3), detecting significant differences $(P<0.01)$ between treatments only in the $3^{\text {rd }}$ week of the data collection period in favor of the control group, with no differences $(P=0.20)$ in the rest of the 10 weeks evaluated $(90 \%$ of cases). A significant reduction in the milk fat content $(-8.0 \%)$ has been reported when supplemented with unsaturated lipids to grazing dairy cows [4]. In line with this result, the milk fat concentration was lower $\left(-7.0 \mathrm{~g} \cdot \mathrm{kg}^{-1}, 21 \%\right.$ reduction) in grazing cows supplemented with unsaturated FA calcium salts $(0.7$ $\mathrm{kg} \cdot \mathrm{day}^{-1}$ ) both in multiparous as in primiparous cows [35]. In addition, the fat content of milk was reduced $(-8.8 \%)$ in alfalfa-grazing multiparous cows that consumed $0.9 \mathrm{~kg} \cdot \mathrm{day}^{-1}$ of unsaturated FA calcium salts in comparison with Control cows (32.2 vs. $35.3 \mathrm{~g} \cdot \mathrm{kg}^{-1}$ ); an effect not found in primiparous cows [37].

The drop in milk fat content could be a consequence of the production of trans FA by hydrogenation at the rumen level of part of the polyunsaturated FAs contained in the calcium salts and their subsequent uptake by the mammary 
gland. These trans FAs are inhibitors of acetyl-CoA carboxylase and de novo lipogenesis in cells of the mammary gland [5] [38] [39]. The capture by the mammary gland of some preformed fatty acids (trans-10 cis-12 CLA and trans- 8 cis-10 CLA) originated during ruminal biohydrogenation in cows supplemented with polyunsaturated FA calcium salts would be responsible for the reduction in activity and/or the expression of genes that encode important enzymes involved in the capture, synthesis and desaturation of fatty acids at the mammary level [5]. It has been proposed that for these trans FAs to be generated in the rumen, two situations should occur: altered ruminal fermentation and the presence of polyunsaturated FAs [40]. Among the risk factors related to altered ruminal fermentation are a low ruminal $\mathrm{pH}$ and a low content of effective fiber in the diet. However, in this study, the ruminal $\mathrm{pH}$ (Table 5) and the NDF content of the diet forage in the cows supplemented with linseed oil calcium salts were $6.10 \%$ and $19.8 \%$, respectively. These conditions would not be predisposing to generate alterations in the biohydrogenation patterns of fats, which would help to explain the absence of a treatment effect on the fat content of milk in 9 of the 10 weeks evaluated.

The protein concentration of milk and the amount of secreted protein were not affected $(P>0.05)$ by the treatments (Table 3$)$. The absence of negative effects on the protein content of milk is an important aspect since this parameter determines the price of milk and affects the speed and quality of coagulation for subsequent transformation into cheese. Under grazing conditions, lipid supplementation generally does not affect the protein concentration of milk [2] [4], while under intensive feeding conditions (100\% TMR diets) this parameter is reduced [41]. On the other hand, protein yield tends to increase $\left(+22.8 \mathrm{~g} \cdot \mathrm{day}^{-1}\right)$ with lipid supplementation as milk production increases [4]. The urea concentration in milk was slightly higher $(+5 \%, P=0.02)$ in the cows supplemented with linseed oil calcium salts (Table 3 ), a result compatible with the higher plasma urea levels observed in this group of cows [42], possibly associated with a lower availability of fermentable energy in the rumen.

\subsection{Dry matter and Energy Intake}

Under stable feeding conditions, supplementation with fats causes an average reduction of $-0.875 \mathrm{~kg} \mathrm{DM} \mathrm{day}^{-1}$ in the intake level of the total DM of the ration [41]. This effect was not detected in the grazing experiments reviewed by [4], since the average decrease reported $\left(-0.9 \mathrm{~kg} \mathrm{DM} \mathrm{day}^{-1}\right)$ was not significantly different from zero $(P>0.16)$. These results are in line with those reported by [2] in their review work where the total DM intake was slightly $\left(-0.3 \mathrm{~kg} \mathrm{DM} \mathrm{day}^{-1}\right)$ but not significantly reduced by lipid supplementation in some grazing experiments. Coincidentally, in this study the total DM intake was similar between treatments (Table 4).

The inclusion of linseed oil calcium salts in the experimental concentrate reduced its voluntary intake (Table 4), a result that could be explained in part by a 
lower palatability of the experimental concentrate and in part by the different amount of concentrate offered (the cows of the control group received $+0.7 \mathrm{~kg}$ $\mathrm{DM} \mathrm{day}^{-1}$ of concentrate). A limitation to take into account when adding lipids to the concentrate from grazing dairy cows is the potential reduction in the palatability of the concentrate supplement [4]. The reductions in concentrate DM intake with the addition of lipids have been attributed to a lower intake rate and size of each meal, which may represent an important limitation under grazing conditions, where the concentrate is supplied twice daily and for a limited time during each milking shift [4].

From the protected lipid supplementation trials under grazing conditions reviewed by [4], only in few of them has individual intake of pasture and total DM been measured and the results are contradictory. Indeed, the addition of hydrogenated vegetable oil to the basal concentrate of cows in early lactation reduced pasture DM intake [3]; however, when the same source of lipids partially replaced the corn grain in the experimental concentrate, pasture DM intake was not affected [10]. A homeostatic regulation of energy intake appeared to have been the most likely mechanism to explain the drop in pasture intake recorded in lipid-supplemented animals [3]. In turn, the supplementation of primiparous and multiparous grazing cows in the first third of lactation with unsaturated FA calcium salts $\left(0.7 \mathrm{~kg} \cdot \mathrm{day}^{-1}\right)$ significantly reduced the voluntary pasture intake in both categories $(-12 \%$ on average), without treatment $\times$ category interaction [35]. A negative effect of the unsaturated FA contained in the supplement on ruminal fermentation and fiber digestibility, due to partial dissociation, would contribute to explaining these results, since it would induce a greater filling of the rumen and a lower rate of passage, depressing consumption.

In this study, pasture DM intake tended $(P=0.06)$ to be higher in the cows supplemented with lipids (Table 4), thus compensating for the lower concentrate intake observed in this group of cows. In line with this result, in a complementary study of ingestive behavior under grazing conditions [43], it was observed that cows supplemented with lipids spent more time grazing $(+48$ $\min \cdot$ day $\left.^{-1}, P<0.05\right)$ and less time resting $\left(-46\right.$ min.day $\left.{ }^{-1}, P<0.05\right)$. Lipid supplementation did not significantly affect any of the parameters associated with the ruminal environment (Table 5), suggesting an adequate protection of lipids that did not alter ruminal metabolism and therefore DM intake.

Total ME intake was similar between treatments (Table 4), coinciding with [44] who reported that the effect of supplementation with protected lipids on energy intake would be null or slightly positive $(+5 \%-7 \%)$.

\subsection{Ruminal Environment}

Lipids that are not adequately protected exert negative effects on ruminal digestion. Hence, a decrease in the molar proportions of acetate and butyrate, an increase in the molar proportion of propionate and a lower concentration of total VFA, together with a decrease in degradability of fiber could be expected [45]. In 
this study, the high dose of lipids used $\left(0.85 \mathrm{~kg} \cdot \mathrm{day}^{-1}\right.$ of linseed oil calcium salts) would be sufficient to induce modifications in the ruminal environment if they were not completely inert. However, the total VFA concentration, the acetate and propionate molar proportions and the acetate:propionate ratio were not affected by the treatments (Table 5). The absence of effect of lipids on the ruminal fermentation pattern suggests that their protection by saponification was effective.

Supplementation with linseed oil calcium salts did not significantly modify the ruminal $\mathrm{pH}$ (Table 5), a result consistent with that reported by other authors in trials conducted under grazing conditions and supplementation with saturated [3] [10] and unsaturated lipids [6] [46]. In the present experiment, the ruminal $\mathrm{pH}$ of the cows supplemented with lipids was above the range of values (5.5 and 6.0) in which, according to [47], a theoretical dissociation of $40 \%$ in polyunsaturated fatty acids calcium salts is expected calculated from the pKa values.

According to [48], the replacement of a part of the concentrate by protected fat in the ruminant diet would increase the concentration of $\mathrm{NH}_{3}-\mathrm{N}$ in the rumen due to an increase in the protein:energy (fermentable carbohydrates) relation of the diet, since FAs are not used as an energy source by the ruminal microflora. Indeed, the use of $\mathrm{NH}_{3}-\mathrm{N}$ by the microbial population depends on the amount of fermentable carbohydrates available in the rumen [49]. In accord with these observations, in the present study the isoenergetic substitution of corn grain for lipids tended $(P=0.12)$ to increase the concentration of $\mathrm{NH}_{3}-\mathrm{N}$ in the rumen, a result compatible with the higher levels of urea in milk observed in cows from group $\mathrm{O} 3$ (Table 3).

\subsection{Fatty Acid Profile}

In this study, supplementation with linseed oil calcium salts reduced $(P<0.05)$ the hypercholesterolemic fraction of milk (C12:0, C14:0 and C16:0). These FAs are the most harmful to health when consumed in excess, since they raise total plasma cholesterol and cholesterol associated with LDL [50]. Myristic acid (C14:0) has the highest atherogenic potential since it has a fourfold stronger effect than palmitic acid on plasma cholesterol levels [51]. The reduction in the concentration of these FAs in milk as a consequence of supplementation with lipids containing polyunsaturated FAs is a well-documented effect [52] [53] [54] that could be explained by the high production of trans FA by hydrogenation at the ruminal level of the polyunsaturated FA contained in calcium salts that are inhibitors of the acetyl-CoA carboxylase enzyme and de novo lipogenesis in the cells of the mammary gland [39].

The average AI of the milk in the cows that received the lipid supplement was $18 \%$ lower $(P<0.01)$ with respect to that of the non-supplemented group (Table 6. The aforementioned reduction in the hypercholesterolemic fraction of milk plus the increase $(13 \%)$ in the concentration of unsaturated FAs (particularly of trans C18:1 and cis-9 trans-11 C18:2) explain the lower average AI of milk ob- 
tained after supplementation.

Rumenic acid (RA, cis-9, trans-11 CLA) and vaccenic acid (VA, trans-11 C18:1) concentrations were higher (28\% and $34 \%$, respectively, $P<0.01$ ) in cows supplemented with lipids with respect to the control group (Table 6). RA has received considerable attention from specialists in human nutrition due to its potential beneficial effects on health, since it plays an important role in the regulation of plasma lipids and cardiovascular functions, reducing the incidence of cancer and inhibiting the tumor growth and metastasis of breast cancer [55]. In addition, VA also has anti-cancer properties and can be metabolized by humans to RA [56]. Many studies corroborate our findings that supplementing rations with oils rich in PUFA increases VA and RA content [57] [58] [59] [60]. The amount of RA in milk depends on the amounts of RA and VA produced in the rumen, together with the activity of $\Delta^{9}$-desaturase in mammary tissue. Endogenous synthesis of RA by $\Delta^{9}$-desaturase activity in the mammary gland was shown to be closely correlated with VA content [60], and [61] observed that changes in the concentration of RA depend fundamentally on the content of VA and, to a lesser extent, on $\Delta^{9}$-desaturase activity. In this study, the increase in the concentration of RA in the milk of the cows supplemented with lipids was associated with an increase in the concentration of VA, but not with an improvement in the activity of the enzyme $\Delta^{9}$-desaturase.

As expected, supplementation with linseed oil calcium salts increased (100\%, $P<0.01)$ the concentrations of $\alpha$-linolenic acid (C18:3 n-3) and total n-3 FA (Table 6) and reduced the n-6/n-3 ratio within the healthy ranges of the diet (< 4:1) [62]. Results of the present study are in accord with several studies evaluating the effects of supplementation with linseed oil on the FA profile of milk [13] [57] [63] [64] [65]. $\alpha$-linolenic acid is a quality factor with functional value since it inhibits platelet aggregation induced by thrombin and prevents the so-called sudden death (coronary mortality) in humans, presenting anti-inflammatory (vascular epithelium) and immunosuppressive effects (inhibits the proliferation of lymphocytes). The average concentration of milk linolenic acid in the study was supported by [66] in their review on 28 publications, in which the average level of C18:3 n-3 in milk ranged from 0.02 to $1.90 \mathrm{~g} \cdot 100 \mathrm{~g} \mathrm{FA}{ }^{-1}$.

\section{Conclusion}

In the present study's experimental conditions, supplementation with linseed oil calcium salts $\left(0.85 \mathrm{~kg} \cdot \mathrm{day}^{-1}\right)$ improved the healthy value of the milk, without effects on milk production and composition, probably due to a similar intake of total energy in the supplemented cows with respect to the control group. Indeed, the lipid supplement used was effective in reducing the hypercholesterolemic fraction of milk and its atherogenicity index, increasing the concentration of vaccenic acid and rumenic acid over basal levels. In turn, it increased the concentration of linolenic acid and total n-3 FA and significantly reduced the n-6/n-3 ratio, thus decreasing the potential risk of coronary heart disease. The 
absence of effect of lipids on the ruminal fermentation pattern suggests that their protection by saponification was effective.

\section{Acknowledgements}

This work was supported by the National Institute of Agricultural Technology (INTA). The authors thank Gabriel Schmidt, Ariel Plattner and Dario Arias for his assistance with the fieldwork, and Tecnuar SRL.

\section{Conflicts of Interest}

The authors declare no conflicts of interest regarding the publication of this paper.

\section{References}

[1] Jacobs, J.L. (2014) Challenges in Ration Formulation in Pasture-Based Milk Production Systems. Animal Production Science, 54, 1130-1140. https://doi.org/10.1071/AN14463

[2] Bargo, F., Muller, L.D., Kolver, E.S. and Delahoy, J.E. (2003) Invited Review. Production and Digestion of Supplemented Dairy Cows on Pasture. Journal of Dairy Science, 86, 1-42. https://doi.org/10.3168/jds.S0022-0302(03)73581-4

[3] Schroeder, G.F., Gagliostro, G.A., Becu-Villalobos, D. and Lacau-Mengido, I. (2002) Supplementation with Partially Hydrogenated Oil in Grazing Dairy Cows in Early Lactation. Journal of Dairy Science, 85, 580-594.

https://doi.org/10.3168/jds.S0022-0302(02)74112-X

[4] Schroeder, G.F., Gagliostro, G.A., Bargo, F., Delahoy, J.E. and Muller, L.D. (2004) Effects of Fat Supplementation on Milk Production and Composition by Dairy Cows on Pasture: A Review. Livestock Production Science, 86, 1-18. https://doi.org/10.1016/S0301-6226(03)00118-0

[5] Bauman, D.E. and Griinari, J.M. (2001) Regulation and Nutritional Manipulation of Milk Fat: Low-Fat Milk Syndrome. Livestock Production Science, 70, 15-29. https://doi.org/10.1016/S0301-6226(01)00195-6

[6] Gagliostro, G.A. and Schroeder, G.F. (2007) Effects of Calcium Salts of Unsaturated Fatty Acids Supplementation on Ruminal Digestion by Grazing Dairy Cows. Archivos Latinoamericanos de Producción Animal, 15, 88-99.

[7] Jenkins, T.C. and Palmquist, D.L. (1984) Effect of Fatty Acids or Calcium Soaps on Rumen and Total Nutrient Digestibility of Dairy Rations. Journal of Dairy Science, 67, 978-986. https://doi.org/10.3168/jds.S0022-0302(84)81396-X

[8] Gagliostro, G.A. (1997) Supplementation with Calcium Salts of Fatty Acids in Mid Lactation Dairy Cows under Grazing Conditions. Revista Argentina de Producción Animal, 17, 83-96.

[9] Gagliostro, G.A. (1998) Protected Lipid Supplementation in Early Lactation Dairy Cows. Effects on Milk Production, Composition, Concentration of Plasma Metabolites and Response to Hormonal Stimuli. Revista Argentina de Producción Animal, $18,85-100$.

[10] Salado, E.E., Gagliostro, G.A., Becu-Villalobos, D. and Lacau-Mengido, I. (2004) Partial Replacement of Corn Grain by Hydrogenated Oil in Grazing Dairy Cows in Early Lactation. Journal of Dairy Science, 87, 1265-1278.

https://doi.org/10.3168/jds.S0022-0302(04)73277-4 
[11] Wijendran, V. and Hayes, K.C. (2004) Dietary n-6 and n-3 Fatty Acid Balance and Cardiovascular Health. Annual Review of Nutrition, 24, 597-615. https://doi.org/10.1146/annurev.nutr.24.012003.132106

[12] Hu, F.B., Manson, J.E. and Willett, W.C. (2001) Types of Dietary Fat and Risk of Coronary Heart Disease: A Critical Review. Journal of the American College of $\mathrm{Nu}$ trition, 20, 5-19. https://doi.org/10.1080/07315724.2001.10719008

[13] Côrtes, C., da Silva-Kazama, D.C., Kazama, R., Gagnon, N., Benchaar, C., Santos, G.T.D., Zeoula, L.M. and Petit, H.V. (2010) Milk Composition, Milk Fatty Acid Profile, Digestion, and Ruminal Fermentation in Dairy Cows Fed Whole Flaxseed and Calcium Salts of Flaxseed Oil. Journal of Dairy Science, 93, 3146-3157. https://doi.org/10.3168/jds.2009-2905

[14] National Research Council (2001) Nutrient Requirements of Dairy Cattle. 7th Edition, National Academy of Sciences, Washington DC, 405 p.

[15] Comeron, E., Romero, L., Peyraud, J.L., Bruno, O. and Delaby, L. (1995) Effects of Herbage Allowance on Performances of Dairy Cows Grazing Alfalfa Swards. Annales de Zootechnie, 44, 368. https://doi.org/10.1051/animres:199505328

[16] Meijs, J.A.C., Walters, R.J.K. and Keen, A. (1982) Sward Methods. In: Leaver, J.D., Ed., Herbage Intake Handbook, The British Grassland Society, Grassland Research Institute, Hurley, 11-37.

[17] AOAC (Association of Official Analytical Chemists) (1990) Official Methods of Analysis. 15th Edition, AOAC, Arlington.

[18] AOAC (Association of Official Analytical Chemists) (1998) Official Methods of Analysis. 16th Edition, AOAC, Arlington.

[19] Komarek, A.R. (1993) An Improved Filtering Technique for the Analysis of Neutral Detergent Fiber and Acid Detergent Fiber Utilizing the Filter Bag Technique. Ankom Technology Corp., Fairport, Publication No. 101, 1-10.

[20] Tilley, J.M.A. and Terry, R.A. (1963) A Two-Stage Technique for in Vitro Digestion of Forage Crops. Journal of the British Grassland Society, 18, 104-111. https://doi.org/10.1111/j.1365-2494.1963.tb00335.x

[21] ISO 9622 IDF 141 (2013) Milk and Liquid Milk Products-Guidelines for the Application of Mid-Infrared Spectrometry.

[22] Ovejero, F. (1987) Chemical and Biological Chemical Evaluation of Forages. Dirección de Desarrollo de Recursos Humanos. COMCAL.

[23] Gaines, W.L. and Davidson, F.A. (1923) Relation between Percentage of Fat Content and Yield of Milk. Illinois Agricultural Experiment Station Bulletin, 245, 275-620.

[24] Tyrrell, H.F. and Reid, J.T. (1965) Prediction of the Energy Value of Cow's Milk. Journal of Dairy Science, 48, 1215-1223. https://doi.org/10.3168/jds.S0022-0302(65)88430-2

[25] Luna, P., Juarez, M. and De La Fuente, M.A. (2005) Validation of a Rapid Milk Fat Separation Method to Determine the Fatty Acid Profile by Gas Chromatography. Journal of Dairy Science, 88, 3377-3381. https://doi.org/10.3168/jds.S0022-0302(05)73021-6

[26] ISO 15884 IDF 182 (2002) Milk Fat-Preparation of Fatty acid Methyl Esters. International Standardisation Organisation/International Dairy Federation, Geneva.

[27] Roche, J.R., Sheahan, A.J., Chagas, L.M. and Berry, D.P. (2007) Concentrate Supplementation Reduces Postprandial Plasma Ghrelin in Grazing Dairy Cows: A Possible Neuroendocrine Basis for Reduced Pasture Intake in Supplemented Cows. 
Journal of Dairy Science, 90, 1354-1363. https://doi.org/10.3168/jds.S0022-0302(07)71622-3

[28] Morales-Almaráz, E., Soldado, A., González, A., Martínez-Fernández, A., Domínguez-Vara, I., de la Roza-Delgado, B. and Vicente, F. (2010) Improving the Fatty Acid Profile of Dairy Cow Milk by Combining Grazing with Feeding of Total Mixed Ration. Journal of Dairy Research, 77, 225-230. https://doi.org/10.1017/S002202991000004X

[29] Noro, M., Sepúlveda, P., Cárdenas, F., Chihuailaf, R.H. and Wittwer, F. (2013) Dorsomedial Rumenocentesis: A Safe Procedure for Collecting Ruminal Fluid Samples from Grazing Dairy Cows. Archivos de Medicina Veterinaria, 45, 25-31. https://doi.org/10.4067/S0301-732X2013000100005

[30] Friggens, N.C., Oldham, J.D., Dewhurst, R.J. and Horgan, G. (1998) Proportions of Volatile Fatty Acids in Relation to the Chemical Composition of Feeds Based on Grass Silage. Journal of Dairy Science, 81, 1331-1344. https://doi.org/10.3168/jds.S0022-0302(98)75696-6

[31] SAS Institute Inc. (2010) SAS/STAT ${ }^{\circ}$ User's Guide (2002-2010). SAS Institute, Cary.

[32] Verité, R. and Journet, M. (1970) Influence of Moisture Content and Dehydration of Grass on its Feed Value for Dairy Cows. Annales de Zootechnie, 19, 255-268. https://doi.org/10.1051/animres:19700302

[33] Minson, D.J. (1990) Forage in Ruminant Nutrition. Academic Press Inc., San Diego, $482 \mathrm{p}$.

[34] Paterson, J.A., Belyea, R.L., Bowman, J.P., Kerley, M.S. and Williams, J.E. (1994) The Impact of Forage Quality and Supplementation Regimen on Ruminant Animal Intake and Performance. In: Fahey Jr., G.C., Ed., Forage Quality, Evaluation and Utilization, ASA, CSSA, SSSA, Madison, 59-114. https://doi.org/10.2134/1994.foragequality.c2

[35] Navarro, A. (2017) Effect of the Supply of Calcium Salts of Polyunsaturated Fatty Acids on the Productive Response of Primiparous and Multiparous Cows in Grazing, Environment and Ruminal Digestion (in Vitro). Magister Scientiae Thesis. Universidad Nacional de Mar del Plata. Facultad de Ciencias Agrarias, Balcarce, 99 p.

[36] Hills, J.L., Wales, W.J., Dunshea, F.R., Garcia, S.C. and Roche, J.R. (2015) Invited Review: An Evaluation of the Likely Effects of Individualized Feeding of Concentrate Supplements to Pasture-Based Dairy Cows. Journal of Dairy Science, 98, 1363-1401. https://doi.org/10.3168/jds.2014-8475

[37] Schroeder, G.F. and Gagliostro, G.A. (2007) Partial Replacement of Corn Grain with Calcium Salts of Fatty Acid in the Concentrate Fed to Grazing Primiparous and Multiparous Dairy Cows. New Zealand Journal of Agricultural Research, 50, 437-449. https://doi.org/10.1080/00288230709510311

[38] Chilliard, Y., Ferlay, A., Mansbridge, R.M. and Doreau, M. (2000) Ruminant Milk Fat Plasticity: Nutritional Control of Saturated, Polyunsaturated, Trans and Conjugated Fatty Acids. Annales de Zootechnie, 49, 181-205. https://doi.org/10.1051/animres:2000117

[39] Chilliard, Y. and Ferlay, A. (2004) Dietary Lipids and Forages Interactions on Cow and Goat Milk Acid Composition and Sensory Properties. Reproduction Nutrition Development, 44, 467-492. https://doi.org/10.1051/rnd:2004052

[40] Latrille, L. (2010) Ruminal Lipid Metabolism. In: Contreras, P.A. and Noro, M., Eds., Rumen: Morphophysiology, Disorders and Modulation of Fermentative Activity, 3rd Edition, América, Valdivia, 47-60.

[41] Rabiee, A.R., Breinhild, K., Scott, W., Golder, H.M., Block, E. and Lean, I.J. (2012) 
Effect of Fat Additions to Diets of Dairy Cattle on Milk Production and Components: A Meta-Analysis and Metaregression. Journal of Dairy Science, 95, 3225-3247. https://doi.org/10.3168/jds.2011-4895

[42] Iorio, J.D., Moreno, Y.M., Olmeda, M.F., Curletto, D., Scandolo, D.E., Maciel, M.G., Cuatrin, A., Palladino, R.A. and Salado, E.E. (2017) Feeding Calcium Salts of Linseed oil on Parameters of Body Condition and Plasma Metabolites of Dairy Cows in Early Lactation. Revista Argentina de Producción Animal, 37, 340.

[43] Olmeda, M.F., Moreno, Y.M., Iorio, J.D., Curletto, D., Palladino, R.A., Scandolo, D.E., Maciel, M.G. and Salado, E.E. (2017) Feeding Calcium Salts of Protected Linseed Oil Modifies Grazing Behaviour and Dry Matter Intake of Dairy Cows in Early Lactation. Revista Argentina de Producción Animal, 37, 305.

[44] Gagliostro, G.A. and Chilliard, Y. (1992) Use of Protected Lipids in the Nutrition of Dairy Cows. I. Effects on the Production and Composition of Milk, and on the Intake of Dry Matter and Energy. Revista Argentina de Producción Animal, 12, 1-15.

[45] Jenkins, T.C. (1993) Lipid Metabolism in the Rumen. Journal of Dairy Science, 76, 3851-3863. https://doi.org/10.3168/jds.S0022-0302(93)77727-9

[46] Vidaurreta, L.I., Schroeder, G.F. and Gagliostro, G.A. (2002) Ruminal Environment and Pasture Digestion in Grazing Cows Supplemented with Calcium Salts of Unsaturated Fatty Acids (Abstract). Journal of Dairy Science, 85, 312.

[47] Sukhija, P.S. and Palmquist, D.L. (1990) Dissociation of Calcium Soaps of Long-Chain Fatty Acids in Rumen Fluid. Journal of Dairy Science, 73, 1784-1787. https://doi.org/10.3168/jds.S0022-0302(90)78858-3

[48] DePeters, E.J. and Cant, J.P. (1992) Nutritional Factors Influencing the Nitrogen Composition of Bovine Milk: A Review. Journal of Dairy Science, 75, 2043-2070. https://doi.org/10.3168/jds.S0022-0302(92)77964-8

[49] Nocek, J.E. and Russell, J.B. (1988) Protein and Energy as an Integrated System: Relationship of Ruminal Protein and Carbohydrate Availability to Microbial Synthesis and Milk Production. Journal of Dairy Science, 71, 2070-2107. https://doi.org/10.3168/jds.S0022-0302(88)79782-9

[50] Schrezenmeir, J. and Jagla A. (2000) Milk and Diabetes. Journal of the American College of Nutrition, 19, 176-190. https://doi.org/10.1080/07315724.2000.10718087

[51] Ulbricht, T.L.V. and Southgate, D.A.T. (1991) Coronary Heart Disease: Seven Dietary Factors. The Lancet, 338, 985-992. https://doi.org/10.1016/0140-6736(91)91846-M

[52] Abughazaleh, A.A. and Jenkins, T.C. (2004) Short Communication: Docosahexaenoic Acid Promotes Vaccenic Acid Accumulation in Mixed Rumen Cultures When Incubated with Linoleic Acid. Journal of Dairy Science, 87, 1047-1050. https://doi.org/10.3168/jds.S0022-0302(04)73250-6

[53] Zheng, H.C., Liu, J.X., Yao, J.H., Yuan, Q., Ye, H.W., Ye, J.A. and Wu, Y.M. (2005) Effects of Dietary Sources of Vegetable Oils on Performance of High-Yielding Lactating Cows and Conjugated Linoleic Acids in Milk. Journal of Dairy Science, 88, 2037-2042. https://doi.org/10.3168/jds.S0022-0302(05)72880-0

[54] Huang, Y., Schoonmaker, J.P., Bradford, B.J. and Beitz, D.C. (2008) Response of Milk Fatty Acid Composition to Dietary Supplementation of Soy Oil, Conjugated Linoleic Acid, or Both. Journal of Dairy Science, 91, 260-270. https://doi.org/10.3168/jds.2007-0344

[55] Parodi, P.W. (1999) Conjugated Linoleic Acid and Other Anticarcinogenic Agents of Bovine Milk Fat. Journal of Dairy Science, 82, 1339-1349. 
https://doi.org/10.3168/jds.S0022-0302(99)75358-0

[56] Stanton, C., Murphy, J., McGrath, E. and Devery, R. (2003) Animal Feeding Strategies for Conjugates Linoleic Acid Enrichment of Milk. In: Sébédio, J.L., Christie, W.W. and Adloff, R., Eds., Advances in Conjugated Linoleic Acid in Food, AOCS Press, Illinois, Vol. 2, 123-145.

[57] Bu, D.P., Wang, J.Q., Dhiman, T.R. and Liu, S.J. (2007) Effectiveness of Oils Rich in Linoleic and Linolenic Acids to Enhance Conjugated Linoleic Acid in Milk from Dairy Cows. Journal of Dairy Science, 90, 998-1007. https://doi.org/10.3168/jds.S0022-0302(07)71585-0

[58] Flowers, G., Ibrahim, S.A. and AbuGhazaleh, A.A. (2008) Milk Fatty Acid Composition of Grazing Dairy Cows When Supplemented with Linseed Oil. Journal of Dairy Science, 91, 722-730. https://doi.org/10.3168/jds.2007-0410

[59] Fuentes, M.C., Calsamiglia, S., Sánchez, C., González, A., Newbold, J.R., Santos, J.E.P., Rodríguez-Alcalá, L.M. and Fontecha, J. (2008) Effect of Extruded Linseed on Productive and Reproductive Performance of Lactating Dairy Cows. Livestock Science, 113, 144-154. https://doi.org/10.1016/j.livsci.2007.03.005

[60] Caroprese, M., Marzano, A., Marino, R., Gliatta, G., Muschio, A. and Sevi, A. (2010) Flaxseed Supplementation Improves Fatty Acid Profile of Cow Milk. Journal of Dairy Science, 93, 2580-2588. https://doi.org/10.3168/jds.2008-2003

[61] Fievez, V., Vlaeminck, B., Dhanoa, M.S. and Dewhurst, R.J. (2003) Use of Principal Component Analysis to Investigate the Origin of Heptadecenoic and Conjugated Linoleic Acids in Milk. Journal of Dairy Science, 86, 4047-4053. https://doi.org/10.3168/jds.S0022-0302(03)74016-8

[62] Simopoulos, A.P. (2004) Omega-3 Essential Fatty Acid Ratio and Chronic Diseases. Food Reviews International, 20, 77-90. https://doi.org/10.1081/FRI-120028831

[63] Brzóska, F. (2006) Effect of Fatty Acid Calcium Salts from Linseed Oil on the Yield and n-3 Fatty Acid Content of Milk and on Blood Plasma Parameters of Cows. Journal of Animal and Feed Sciences, 15, 347-360. https://doi.org/10.22358/jafs/66906/2006

[64] Suksombat, W., Thanh, L.P., Meeprom, C. and Mirattanaphrai, R. (2016) Effect of Linseed Oil Supplementation on Performance and Milk Fatty Acid Composition in Dairy Cows. Animal Science Journal, 87, 1545-1553. https://doi.org/10.1111/asj.12609

[65] Castro, T., Martinez, D., Isabel, B., Cabezas, A. and Jimeno, V. (2019) Vegetable Oils Rich in Polyunsaturated Fatty Acids Supplementation of Dairy Cows' Diets: Effects on Productive and Reproductive Performance. Animals, 9, 205. https://doi.org/10.3390/ani9050205

[66] Moate, P.J., Chalupa, W., Boston, R.C. and Lean, I.J. (2007) Milk Fatty Acids. I. Variation in the Concentration of Individual Fatty Acids in Bovine Milk. Journal of Dairy Science, 90, 4730-4739. https://doi.org/10.3168/jds.2007-0225 